\title{
HIGHLY EFFICIENT SYNTHESIS OF 2,4-DISUBSTITUTED OXAZOLES THROUGH PALLADIUM/COPPER COMEDIATED DIRECT ARYLATION REACTION
}

\section{VENKATA REDDY REGALLA ${ }^{1,2}$, RAMA KRISHNAM RAJU ADDADA ${ }^{1,2}$, VENKAT SWAMY PULI ${ }^{1,2}$, ABHISHEK S SAXENA ${ }^{2}$, ANINDITA CHATTERJEE ${ }^{1 *}$}

${ }^{1}$ Department of Chemistry, Koneru Lakshmaiah University, Vaddeswaram, Guntur, Andhra Pradesh, India. ${ }^{2}$ GVK Biosciences Private Limited, Medicinal Chemistry Division, 28A, IDA, Nacharam, Hyderabad, Telangana, India. Email: anindita.chatterjee2709@gmail.com

Received: 21 March 2018, Revised and Accepted: 09 May 2018

ABSTRACT

Objective: The aim of the present study is to synthesize 2,4-disubstituted oxazoles through palladium/copper comediated direct arylation reaction.

Methods: 2,4-disubstituted oxazoles (3a-i) have been synthesized by the reaction of 4-substituted oxazole with aryl bromide in the presence of $\mathrm{KOH}, \mathrm{CuI}$ and $\mathrm{Pd}(\mathrm{PPh} 3) 4$ in dimethoxyethane. Titled compounds (3a-i) were obtained in good yields using an expedient two-step synthesis of 2,4-disubstituted oxazoles from commercially available starting materials

Results: The structures of the newly synthesized compounds were characterized by Fourier-transform infrared, 1H NMR, 13C NMR, and mass spectral studies. This method can be an efficient method for the synthesis of 2,4-disubstituted oxazoles (3a-i).

Conclusion: Pd(PPh3)4 and CuI cocatalytic system direct arylation of 4-aryl/alkyl oxazoles with various aryl bromides has been developed to generate 2,4-disubstituted oxazoles. The high functional group tolerance and the speed of the reaction afford this method appropriate for the combinatorial synthesis of a variety of 2,4-disubstituted oxazoles.

Keywords: Oxazoles, Arylation, Palladium/copper.

(C) 2018 The Authors. Published by Innovare Academic Sciences Pvt Ltd. This is an open access article under the CC BY license (http://creativecommons. org/licenses/by/4. 0/) DOI: http://dx.doi.org/10.22159/ajpcr.2018.v11i8.26125

\section{INTRODUCTION}

Oxazoles are one of the common substructures in a wide variety of biologically active compounds, synthetic intermediates, and pharmaceuticals [1]. Many approaches for the synthesis of such molecules have emerged, involving the building of the oxazole ring by nontrivial multistep reaction sequences. Since oxazole derivatives have wide spread applications in medicinal chemistry [2]. Much effort has been focused toward devising methods for the synthesis of substituted oxazoles [3]. The activation of a $\mathrm{C}-\mathrm{H}$ bond by transitionmetal catalysis has received increasing interest recently and constitutes one of the most significant fields of modern organic chemistry [4]. In this regard, various metals, such as $\mathrm{Rh},{ }^{5 a} \mathrm{Ru}^{5 \mathrm{~b}} \mathrm{Fe},{ }^{5 \mathrm{c}} \mathrm{Cu},{ }^{5 \mathrm{~d}} \mathrm{Ag}{ }^{5 \mathrm{e}}$ and $\mathrm{Pd}{ }^{5 \mathrm{f}}$ have made remarkable contributions[5]. However, much less work has been reported for the preparation of oxygen-containing heterocycles through palladium catalyzed $\mathrm{C}-\mathrm{H}$ activation.

Among the oxazole-type compounds, benzoxazoles and 2-phenyloxazoles are the most frequently encountered substrates [6]. Therefore, various synthetic methods have been developed for the concise and efficient synthesis of highly substituted oxazole structures $[7,8]$. Direct arylations at the 2-position of monosubstituted oxazoles with aryl halides are much less well documented. Hoarau et al. have described a regioselective palladium-catalyzed C-2 arylation of ethyl 4-oxazolecarboxylate with iodobenzene, while Li et al. have reported the $\mathrm{C}-2$ arylation of methyl 4-aryl-5-oxazole carboxylate with aryl iodides under classical conditions in the presence of copper(I) iodide [9,10]. Li J et al. have recently reported the arylation of azoles, and indoles using ArSO2Na and ArSO2Cl [11]. In recently, Tamagnan further reported the first example of $\mathrm{Pd}(0) / \mathrm{Cu}(\mathrm{I})$ catalyzed direct arylation of benzoxazole [12]. In addition, Hachiya et al. developed $\mathrm{Ni}(\mathrm{II})$-catalyzed direct arylation of benzoxazoles and oxazoles with arylboronic acids under oxygen [13]. In this context, a study of the direct metal-catalyzed arylation of 4-substituted oxazoles with aryl bromides, being together cheaper and more broadly available than the corresponding iodides, was undertaken.

\section{METHODS}

We herein report a simple and convenient approach for the synthesis of 2,4-disubstituted oxazoles through the arylation of 4-substituted oxazole in a single step. As a model reaction, the coupling of 4-phenyloxazole 1a with bromobenzene was primarily studied. Compound 1a was readily prepared from phenacyl bromide in one step in $75 \%$ yield [14]. We initiated our studies with the screening of the conditions for the coupling of oxazole (1a) and bromobenzene (2a) under palladium catalysis. Initially, when $\mathrm{Pd}(\mathrm{PPh} 3)_{4}(5 \mathrm{~mol} \%)$ was selected as the catalyst and $\mathrm{Cu}(\mathrm{OAc})_{2}(1$ equiv.) was used as an oxidant in dimethoxyethane in the presence of 1 equiv. of $\mathrm{KOH}$ base, the coupled product was obtained in $45 \%$ yield (Table 1, Entry e). Under these conditions, other protic and aprotic solvents examined proved less favorable. The efficiency was further affected by an oxidant. The yield was improved from $45 \%$ to $78 \%$ when 1 equiv. of CuI was applied (Table 1, Entry b). To optimize the reaction conditions, several copper catalysts such as $\mathrm{Cu}(\mathrm{OTf})_{2}, \mathrm{Cu}(\mathrm{OTf}), \mathrm{CuCl}$, and $\mathrm{CuI}$ were screened. Among them, 1 eq. of $\mathrm{CuI}$ gave the best results in terms of conversion (Fig. 2). Next, we studied the effect of solvent. Of various solvents, dimethoxyethane was found to be effective resulting in the formation of $3 \mathrm{a}$ in high yields. Therefore, optimal conditions for reaction were $\mathrm{Pd}(\mathrm{PPh} 3) 4$ (5 mol \%), CuI (1 equiv.), and $\mathrm{KOH}$ (1 equiv.) in dimethoxyethane (DME) at $120^{\circ} \mathrm{C}$.

Next, we extended this method to other aromatic aryl halides such as 3,4,5-trimethoxy bromobenzene, 4-methyl benzene, 3,4-dimthoxy bromobenzene, and 3-methyl bromobenzene. In all cases, the corresponding 2,4-disubstituted oxazole derivatives were obtained in good yields (Entries b, c, and d, Fig. 3). Next, we examined the reactivity of different 4-aryl-substituted oxazoles; interestingly, we are observed good yields (Entry f, Fig. 3). In addition, this method works not only 
Table 1: Screening the cocatalysts in the formation of $3 \mathrm{a}^{\mathrm{a}}$

\begin{tabular}{llllll}
\hline Entry & Co-Catalyst & Equiv. & Solvent & Time (h) & Yield (\%) \\
\hline a & CuI & 0.5 & DME & 6 & 55 \\
b & CuI & 1 & $"$ & $"$ & 78 \\
c & CuI & 1.5 & $"$ & $"$ & 63 \\
d & CuI & 2 & $"$ & $"$ & 60 \\
e & Cu (OAc) & 1 & $"$ & $"$ & 45 \\
f & CuOTf & 1 & $"$ & $"$ & 40 \\
g & Cu (OTf) & 1 & $"$ & $"$ & 35 \\
h & CuCl & 1 & $"$ & $"$ & 60 \\
\hline
\end{tabular}

a Reaction was performed at $0.5 \mathrm{mmol}$ scale with respect to oxazole, byield refers to pure product after column chromatography. DME: Dimethoxyethane

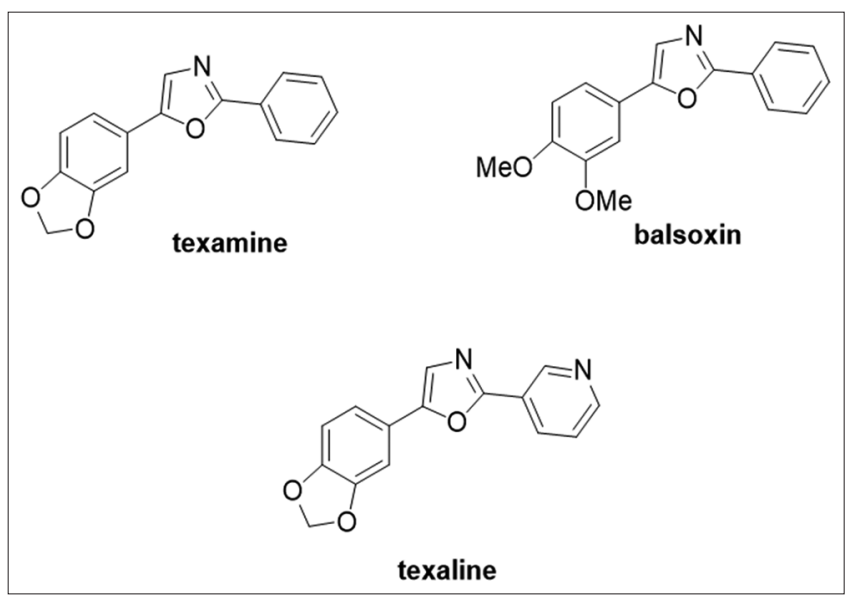

Fig. 1: Biologically active natural products

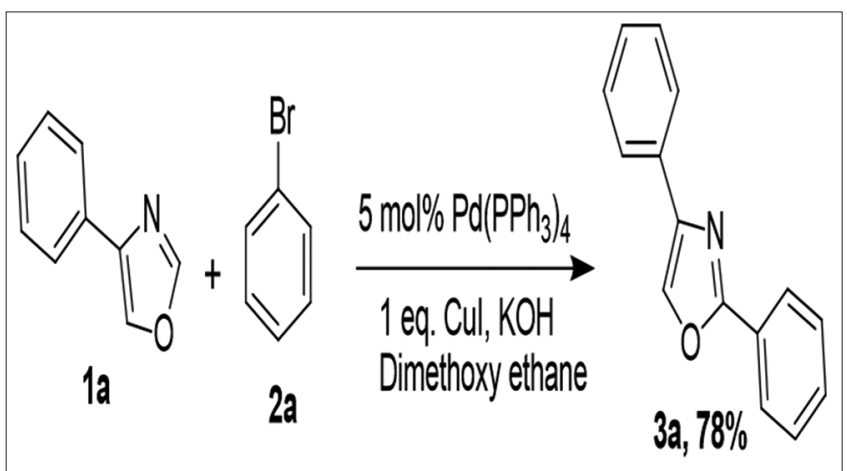

Fig. 2: Synthesis of 2,4-diphenyloxazole (3a)

with aromatic oxazoles but also with aliphatic oxazoles. In case of aliphatic oxazoles, the corresponding 2,4-alkyl-substituted oxazoles were obtained relatively in lower yields (Entries g, h, I, and j, Fig. 3) than aromatic counterpart. In all the cases, the reactions proceeded efficiently in the presence of $5 \mathrm{~mol} \% \mathrm{Pd}(\mathrm{PPh} 3)_{4^{\prime}} 1$ eq. CuI, and 1 eq. $\mathrm{KOH}$ at $120^{\circ} \mathrm{C}$ in dimethoxyethane, and the corresponding products were obtained in good yields.

To show the synthetic utility, we applied the present protocol to the synthesis of an analog of balsoxin and texamine. The 2,5-diaryloxazole motif is originate in a variety of natural products such as texamine and balsoxin (Fig. 1), which were isolated from the roots of Amyris texana and Amyris plumieri, respectively. Here, we synthesized 2,4-diaryloxazole analogs of texamine and balsoxin in one step from commercially available starting materials (Fig. 4). This procedure is efficient and practical compared to previous methods.

\section{RESULTS AND DISCUSSION}

$1 \mathrm{H}$ and 13C nuclear magnetic resonance (NMR) spectra were recorded on BrukerAvance $500 \mathrm{MHz}, 300 \mathrm{MHz}$, and ${ }^{13} \mathrm{C}$ NMR at $125 \mathrm{MHz}, 75 \mathrm{MHz}$. For ${ }^{1} \mathrm{H}$ NMR, tetramethylsilane was used as internal standard $(\delta=0)$ and the values are reported as follows: Chemical shift, integration, multiplicity (s=singlet, $\mathrm{d}=$ doublet, $\mathrm{t}=$ triplet, $\mathrm{q}=$ quartet, $\mathrm{m}=$ multiplet, and $\mathrm{br}=$ broad), and the coupling constants in $\mathrm{Hz}$. For ${ }^{13} \mathrm{C} \mathrm{NMR}, \mathrm{CDCl}_{3}(\delta=77.27)$ was used as internal standard and spectra were obtained with complete proton decoupling. Low-resolution mass spectrometry (MS) and high-resolution MS (HRMS) data were obtained using a VG AutoSpec triple sector MS (electrospray ionization [ESI] ionization). Melting points were measured on measured on a Triad Scientific micromelting point apparatus. Commercially available aryl halides, $\mathrm{Pd}\left(\mathrm{PPh}_{3}\right)_{4}, \mathrm{CuI}$, and $\mathrm{KOH}$ were used without further purification. DME was distilled from $\mathrm{CaH}$ under $\mathrm{N}_{2}$ atmosphere.

\section{General procedure}

A mixture of 4-substituted oxazole $(1 \mathrm{mmol})$, aryl bromide $(1 \mathrm{mmol})$, $\mathrm{KOH}(1 \mathrm{mmol})$, and $\mathrm{CuI}(1 \mathrm{mmol})$ in dimethoxyethane $(10 \mathrm{~mL})$ was stirred at RT for $10 \mathrm{~min}$ and degassed with argon for $20 \mathrm{~min}$. Then, $\mathrm{Pd}\left(\mathrm{PPh}_{3}\right)_{4}(5 \mathrm{~mol} \%)$ was added and reflux for the appropriate time. After completion of the reaction as indicated by thin-layer chromatography, the reaction mixture was quenched with water and extracted with ethyl acetate $(2 \times 15 \mathrm{~mL})$. Evaporation of the solvent followed by purification on silica gel afforded the pure disubstituted oxazole.

\section{2,5-Diphenyloxazole (3a)}

Solid, m.p.72-74 ${ }^{\circ} \mathrm{C} ;{ }^{1} \mathrm{H}$ NMR (500 MHz, $\left.\mathrm{CDCl}_{3}\right)$ : $\delta 8.14-8.06(\mathrm{~m}, 2 \mathrm{H})$, $7.92(\mathrm{~s}, 1 \mathrm{H}), 7.80-7.77(\mathrm{~m}, 2 \mathrm{H}), 7.48-7.36(\mathrm{~m}, 5 \mathrm{H}), 7.31-7.25(\mathrm{~m}, 1 \mathrm{H})$ ppm; ${ }^{13} \mathrm{C}$ NMR $\left(75 \mathrm{MHz}, \mathrm{CDCl}_{3}\right.$ ): $\delta 160.8,141.2,132.7,130.4,129.7$, 128.0, 127.4, 126.9, 125.9, 125.0 ppm; MS (ESI): $m / z\left([\mathrm{M}+\mathrm{H}]^{+}\right): 222$; HRMS (ESI): $m / z$ zalcd for $\mathrm{C}_{15} \mathrm{H}_{12} \mathrm{NO}$ : 222.0918; found: 222.0923 .

\section{5-phenyl-2-(3,4,5-trimethoxyphenyl)oxazole (3b)}

Semi solid; ${ }^{1} \mathrm{H}$ NMR $\left(300 \mathrm{MHz}, \mathrm{CDCl}_{3}\right)$ : $\delta 8.11-8.09(\mathrm{~m}, 2 \mathrm{H}), 7.86(\mathrm{~s}$, 1H), 7.47-7.42 (m, 2H), 7.17 (s, 1H), 6.99 (s, 2H), 3.94 (s, 6H), 3.84 (s, $3 \mathrm{H}) \mathrm{ppm} ;{ }^{13} \mathrm{C}$ NMR $\left(75 \mathrm{MHz}, \mathrm{CDCl}_{3}\right): \delta 161.7,153.5,141.8,133.1,130.4$, 128.7, 127.3, 126.7, 126.4, 106.0, 102.7, 60.9, 56.2, 56.1 ppm; MS (ESI): $\mathrm{m} / \mathrm{z}\left([\mathrm{M}+\mathrm{H}]^{+}\right): 312$; HRMS (ESI): $\mathrm{m} / z$ calcd for $\mathrm{C}_{18} \mathrm{H}_{17} \mathrm{NO}_{4} \mathrm{Na}$ : 334.1055; found: 334.1058 .

\section{5-phenyl-2-p-tolyloxazole (3c)}

Solid, m.p.70-72 ${ }^{\circ} \mathrm{C} ;{ }^{1} \mathrm{H}$ NMR (500 MHz, $\left.\mathrm{CDCl}_{3}\right)$ : $\delta 8.11-8.08(\mathrm{~m}, 2 \mathrm{H})$, 7.89 (s, 1H), 7.61-7.54 (m, 2H), 7.47-7.41 (m, 3H), 7.26-7.22 (m, 2H), 7.07 (d, $J=7.5 \mathrm{~Hz}, 1 \mathrm{H}), 2.41(\mathrm{~s}, 3 \mathrm{H}) \mathrm{ppm} ;{ }^{13} \mathrm{C}$ NMR $\left(75 \mathrm{MHz}, \mathrm{CDCl}_{3}\right)$ : $\delta 161.5,150.8,141.1,129.7,128.9,128.7,128.0,126.4,124.9,124.3$, 123.0, 21.8 ppm; MS (ESI): $m / z\left([\mathrm{M}+\mathrm{H}]^{+}\right): 236$

2-(3,4-dimethoxyphenyl)-5-phenyloxazole (3k)

Solid, m.p.98-100 ${ }^{\circ} \mathrm{C} ;{ }^{1} \mathrm{H}$ NMR (500 MHz, $\left.\mathrm{CDCl}_{3}\right): \delta 8.12-8.10(\mathrm{~m}, 2 \mathrm{H})$, 7.53-7.46 (m, 2H), $7.36(\mathrm{~s}, 1 \mathrm{H}), 7.33(\mathrm{dd}, J=1.9 \mathrm{~Hz}, J=6.3 \mathrm{~Hz}, 1 \mathrm{H}), 7.22$ (d, $J=1.9 \mathrm{~Hz}, 1 \mathrm{H}), 6.96(\mathrm{~d}, J=8.3 \mathrm{~Hz}, 1 \mathrm{H}), 4.01(\mathrm{~s}, 3 \mathrm{H}), 3.96(\mathrm{~s}, 3 \mathrm{H}) \mathrm{ppm}$; ${ }^{13} \mathrm{C}$ NMR $\left(125 \mathrm{MHz}, \mathrm{CDCl}_{3}\right.$ ): $\delta 160.0,150.7,148.9,148.7,129.7,128.4$, $127.1,125.7,121.8,120.7,116.9,111.2,107.2,56.1,56.1$ ppm; MS (ESI): $m / z\left([\mathrm{M}+\mathrm{H}]^{+}\right): 282$.

\section{2-(benzo[d][1,3]dioxol-5-yl)-5-phenyloxazole (3l)}

Solid, m.p.136-138 ${ }^{\circ} \mathrm{C} .{ }^{1} \mathrm{H}$ NMR (300 MHz, CDCl3) 8.08-8.06 (m, 2H), $7.51-7.48(\mathrm{~m}, 3 \mathrm{H}), 7.33(\mathrm{~s}, 1 \mathrm{H}), 7.26(\mathrm{dd}, J=8.2 \mathrm{~Hz}, J=1.6 \mathrm{~Hz}, 1 \mathrm{H}), 7.18$ (d, $J=1.5 \mathrm{~Hz}, 1 \mathrm{H}), 6.88$ (d, $J=8.2 \mathrm{~Hz}, 1 \mathrm{H}), 6.06$ (s, 2H); MS (ESI): $m / z$ $\left([\mathrm{M}+\mathrm{H}]^{+}\right): 266$.

\section{5-phenyl-2-p-tolyloxazole (3f)}

Solid, m.p.70-72 ${ }^{\circ}$; ${ }^{1}{ }^{\mathrm{H}}$ NMR $\left(500 \mathrm{MHz}, \mathrm{CDCl}_{3}\right): \delta 8.13-8.09(\mathrm{~m}, 2 \mathrm{H})$, $7.83(\mathrm{~s}, 1 \mathrm{H}), 7.62-7.51(\mathrm{~m}, 2 \mathrm{H}), 7.43-7.40(\mathrm{~m}, 3 \mathrm{H}), 7.2-7.20(\mathrm{~m}, 2 \mathrm{H})$, $7.03(\mathrm{~d}, J=7.5 \mathrm{~Hz}, 1 \mathrm{H}), 2.45(\mathrm{~s}, 3 \mathrm{H}) \mathrm{ppm}$; MS (ESI): $m / z\left([\mathrm{M}+\mathrm{H}]^{+}\right): 236$.

\section{2-Ethyl-5-phenyloxazole (3g)}

Semi solid; ${ }^{1} \mathrm{H}$ NMR (500 MHz, $\mathrm{CDCl}_{3}$ ): $\delta 8.03-7.96$ (m, 2H), 7.44-7.35 $(\mathrm{m}, 4 \mathrm{H}), 2.65-2.54(\mathrm{q}, J=8.6 \mathrm{~Hz}, J=15.0 \mathrm{~Hz}, 2 \mathrm{H}), 1.28(\mathrm{t}, J=7.5 \mathrm{~Hz}$, 


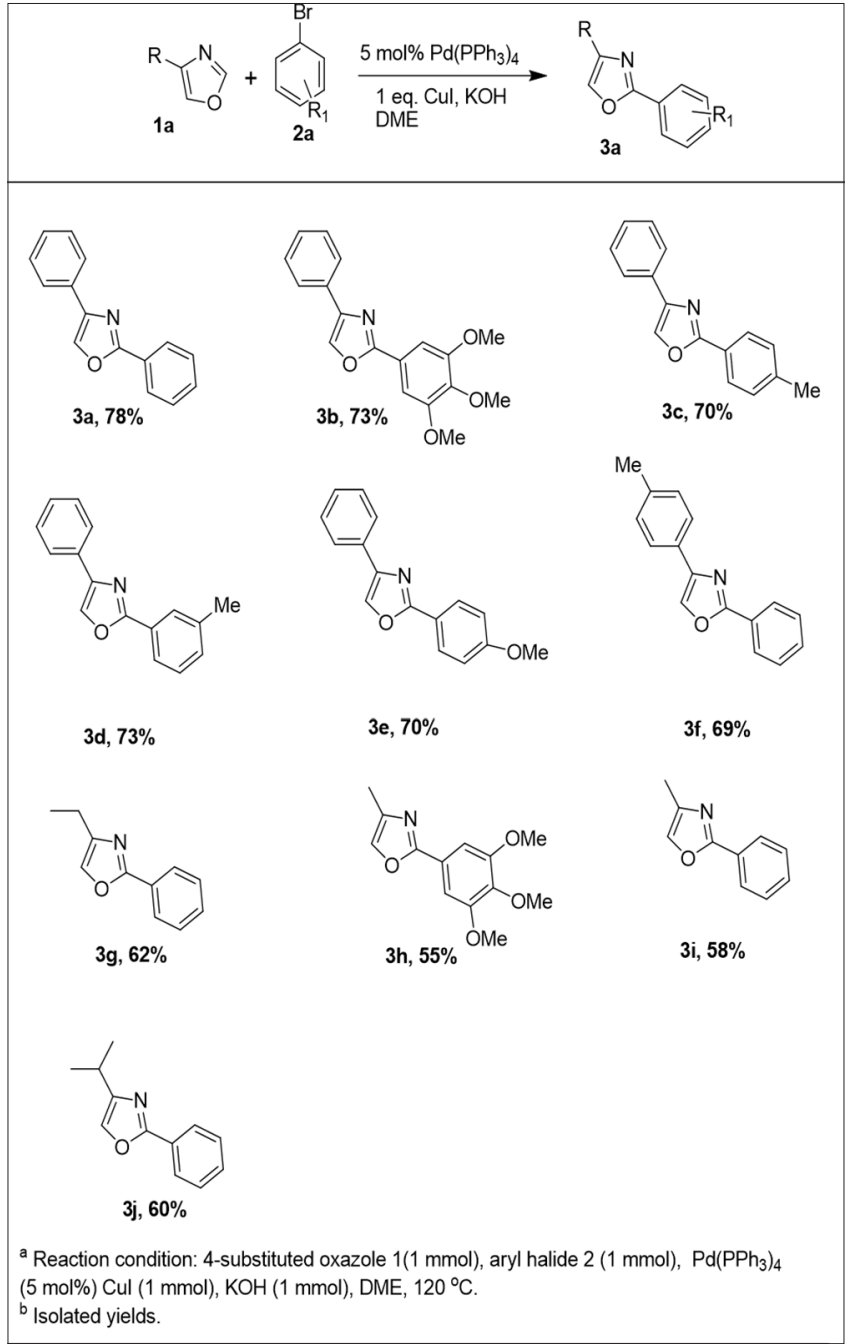

Fig. 3: Reaction screening with different aryl bromides

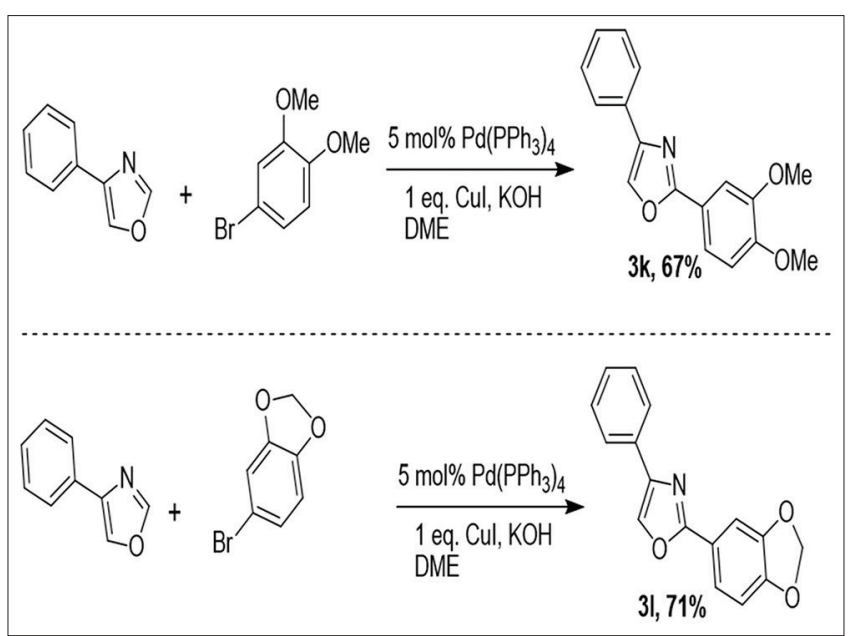

Fig. 4: Synthesis of texamine and balsoxin analogs $3 \mathrm{k}$ and 31

3H) ppm; ${ }^{13} \mathrm{C}$ NMR (75 MHz, $\left.\mathrm{CDCl}_{3}\right): \delta 158.1,129.7,128.6,127.8,125.9$, 122.0, 28.3, 17.2.ppm; MS (ESI): $m / z\left([\mathrm{M}+\mathrm{H}]^{+}\right): 174$.

5-Phenyl-2-(3,4,5-trimethoxyphenyl)oxazole (3h)

Semi solid; ${ }^{1} \mathrm{H}$ NMR $\left(500 \mathrm{MHz}, \mathrm{CDCl}_{3}\right.$ ): $\delta 7.70$ (s, 1H), 6.87 (s, 2H), 3.90 (s, 6H), $3.82(\mathrm{~s}, 3 \mathrm{H}), 2.50(\mathrm{~s}, 3 \mathrm{H}) \mathrm{ppm} ;{ }^{13} \mathrm{C} \mathrm{NMR}\left(75 \mathrm{MHz}, \mathrm{CDCl}_{3}\right): \delta 160.7$,
152.5, 139.7, 137.1, 132.1, 126.1, 102.2, 61.0, 56.3, 14.6 ppm;MS (ESI): $\mathrm{m} / \mathrm{z}\left([\mathrm{M}+\mathrm{Na}]^{+}\right): 272$; HRMS (ESI): $\mathrm{m} / z$ zalcd for $\mathrm{C}_{13} \mathrm{H}_{15} \mathrm{NO}_{4} \mathrm{Na}$ : 272.0898; found: 272.0895 .

\section{5-Methyl-2-phenyloxazole (3i)}

Semi solid; ${ }^{1} \mathrm{H}$ NMR (500 MHz, $\mathrm{CDCl}_{3}$ ): $\delta 7.75(\mathrm{~s}, 1 \mathrm{H}), 7.64$ (d, $J=8.0 \mathrm{~Hz}$, $2 \mathrm{H}), 7.34(\mathrm{t}, J=7.5 \mathrm{~Hz}, 2 \mathrm{H}), 7.25-7.21(\mathrm{~m}, 1 \mathrm{H}), 2.50(\mathrm{~m}, 3 \mathrm{H}) \mathrm{ppm}$; ${ }^{13} \mathrm{C}$ NMR $\left(75 \mathrm{MHz}, \mathrm{CDCl}_{3}\right): \delta 160.7,139.8,132.4,128.0,127.2,124.7$, 14.7 ppm; MS (ESI): $m / z\left(\left[M+{ }^{+}\right]^{+}\right): 160$; HRMS (ESI): $m / z c a l c d$ for $\mathrm{C}_{10} \mathrm{H}_{10} \mathrm{NO}: 160.0762$; found: 160.0769 .

\section{2-Isopropyl-5-phenyloxazole (3j)}

Semi solid; ${ }^{1} \mathrm{H}$ NMR (300 MHz, $\mathrm{CDCl}_{3}$ ): $\delta 8.01-7.97(\mathrm{~m}, 2 \mathrm{H}), 7.42-7.37$ $(\mathrm{m}, 3 \mathrm{H}), 7.33(\mathrm{~d}, J=1.0 \mathrm{~Hz}, 1 \mathrm{H}), 2.86-2.83(\mathrm{~m}, 1 \mathrm{H}), 1.29(\mathrm{~d}, J=6.8 \mathrm{~Hz}$, $6 \mathrm{H}) \mathrm{ppm} ;{ }^{13} \mathrm{C}$ NMR $\left(75 \mathrm{MHz}, \mathrm{CDCl}_{3}\right): \delta 160.6,158.1,129.7,128.6,127.8$, $125.9,121.7,26.2,20.6$ ppm; MS (ESI): $m / z\left([\mathrm{M}+\mathrm{H}]^{+}\right): 188$.

On the basis of these results, a mechanism is proposed; initially, the Pd catalyst reacted with bromo compound $2 \mathrm{a}$ in the presence of base and forms species $\mathrm{Pd}(\mathrm{II}) \mathrm{A}$. Then, A is proposed to interact with oxazole $1 \mathrm{a}$, leading to $\mathrm{C}-\mathrm{H}$ activation and formation of a palladium(II) aryl-heteroaryl intermediate $\mathrm{B}, \mathrm{C}-\mathrm{C}$ reductive elimination, of which furnishes product $3 \mathrm{a}$. The catalytic cycle is completed when the $\operatorname{Pd}(0)$ species is oxidized to Pd(II) by CuI.

\section{CONCLUSION}

$\mathrm{Pd}(\mathrm{PPh} 3)_{4}$ and CuI cocatalytic system direct arylation of 4-aryl/alkyl oxazoles with various aryl bromides has been developed to generate 2,4-disubstituted oxazoles. This methodology is illustrated by an expedient two-step synthesis of the four 2,4-disubstituted oxazoles from commercially available starting materials. The high functional group tolerance and the speed of the reaction afford this method appropriate for the combinatorial synthesis of a variety of 2,4-disubstituted oxazoles. Studies on additional applications of this direct arylation procedure with aryl/alkyl boronic acids and other heterocycles are in progress in our laboratory.

\section{AUTHORS' CONTRIBUTIONS}

Manuscript was prepared by Venkata Reddy Regalla.

\section{CONFLICTS OF INTEREST}

The authors declare that they have no conflicts of interest.

\section{REFERENCES}

1. (a) Wipf P. Synthetic studies of biologically active marine cyclopeptides. Chem Rev 1995;95:2115-34. (b) Jin Z. Muscarine, imidazole, oxazole, and thiazole alkaloids. Nat Prod Rep 2003;20:584-605.

2. (a) McGovern SL, Caselli E, Grigorieff N, Shoichet BK. A common mechanism underlying promiscuous inhibitors from virtual and highthroughput screening. J Med Chem 2002;45:1712-22. (b) MurciaSoler M, Perez-Gimenez F, Garcia-March FJ, Salabert-Salvador MT, Diaz-Villanueva W, Castro-Bleda MJ, et al. Drugs and nondrugs: An effective discrimination with topological methods and artificial neural networks. J Chem Inf Comput Sci 2004;44:1031-41.

3. Sarkate AP, Shinde DP. Synthesis and docking studies of 2-(nitrooxy)-ethyl-2-(substituted-2,5-diphenyl-oxazole)-acetate as anti-inflammatory agents with analgesic and nitric oxide releasing properties. Int J Pharm Pharm Sci 2015;7:128-34.

4. Parlapalli A, Cidda KM, Manda S. Antiinflammatory and antioxidant activities of 2-amino-n-(substitutedalkyl)benzoxazole-5-carboxamide derivatives. Int J Pharm Pharm Sci 2014:6:311-4.

5. (a) Lewis JC, Bergman RG, Ellman JA. Direct functionalization of nitrogen heterocycles via Rh-catalyzed C-H bond activation. Acc Chem Res 2008:41:1013-25. (b) Ritleng V, Sirlin C, Pfeffer M. Ru-, Rh-, and $\mathrm{Pd}$-catalyzed C-C bond formation involving $\mathrm{C}-\mathrm{H}$ activation and addition on unsaturated substrates: Reactions and mechanistic aspects. Chem Rev 2002;102:1731-70. (c) Zhao BG, Han ZB, Ding KL. Organometallic catalysis. Angew Chem Int Ed 2013;52:4744-88. (d) Sakakura A, Ishihara K. Rational design of highly effective asymmetric Diels- 
Alder catalysts bearing 4,4'-sulfonamidomethyl groups. Chem Soc Rev 2011;40:163-72. (e) Pati K, Liu RS. Gold-catalyzed synthesis of substituted 2-aminofurans via formal [4+1]-cycloadditions on 3-en-1ynamides. Chem Commun 2012;48:6049-51. (f) Tietze LF, Ila H, Bell HP. Enantioselective palladium-catalyzed transformations. Chem Rev 2004; 104:3453-516.

6. (a) Do HQ, Daugulis OJ. Copper-catalyzed arylation of heterocycle CH bonds. Am Chem Soc 2007;129:12404. (b) Turner GL, Morris JA, Greaney MF. Direct arylation of thiazoles on water. Angew Chem Int Ed 2007;46:7996. (c) Sanchez RS, Zhuravlev A. Mechanistic evidence for a ring-opening pathway in the Pd-catalyzed direct arylation of benzoxazoles. J Am Chem Soc 2007;129:5824.

7. (a) Turchi IJ, Dewar MJ. Chem Rev 1975;75:389-437. (b) Turchi IJ. Ind Eng Chem Prod Res Dev 1981;20:32-76.

8. (a) Shi B, Blake AJ, Lewis W, Campbell IB, Judkins BD, Moody CJ. Rhodium carbene routes to oxazoles and thiazoles. Catalyst Effects in the synthesis of oxazole and thiazole carboxylates, phosphonates, and sulfones. J Org Chem 2010;75:152-61. (b) Xie J, Jiang H, Cheng Y, Zhu C. Metal-free, organocatalytic cascade formation of $\mathrm{C}-\mathrm{N}$ and $\mathrm{C}-\mathrm{O}$ bonds through dual sp3 $\mathrm{C}-\mathrm{H}$ activation: Oxidative synthesis of oxazole derivatives. Chem Commun 2012;48:979-81. (c) Xue WJ, Li Q, Zhu YP, Wang JG, Wu AX.Convergent integration of two self-labor domino sequences: a novel method for the synthesis of oxazole derivatives from methyl ketones and benzoins. Chem Commun 2012;48:3485-7.
9. Hoarau C, Du Fou de Kerdaniel A, Bracq N, Grandclaudon P, Couture A, Marsais F. Regioselective palladium-catalyzed phenylation of ethyl 4-oxazolecarboxylate. Tetrahedron Lett 2005;46:8573.

10. Li X, Murray WV, Macielag MJ, Guan Q. U.S. Patent 113522 A1; 2005.

11. Li J, Chen J, Gui C, Zhang L, Qin Y, Xu Q, et al. Design, synthesis and antitumor evaluation of a new series of N-substituted-thiourea derivatives. Bio Org Med Chem 2006;14:2209-24.

12. (a) Chen R, Liu S, Liu X, Yang L, Deng G. Palladium-catalyzed desulfitative $\mathrm{C}-\mathrm{H}$ arylation of azoles with sodium sulfinates. Org Biomol Chem 2011;9:7675. (b) Wu M, Luo J, Xiao F, Zhang S, Deng GJ, Luo HA. Palladium-catalyzed direct and Site-selective desulfitative arylation of indoles with sodium sulfinates. Adv Synth Catal 2012;354:335. (c) Wang M, Li D, Zhou W, Wang L. A highly efficient palladium-catalyzed desulfitative arylation of azoles with sodium arylsulfinates. Tetrahedron 2012;68:1926. (d) Zhang M, Zhang S, Liu M, Cheng J. Palladium-catalyzed desulfitative C-arylation of a benzo[d]oxazole $\mathrm{C}-\mathrm{H}$ bond with arene sulfonyl chlorides. Chem Commun 2011;47:11522.

13. Hachiya H, Hirano K, Satoh T, Miura M. Oxidative nickel-air catalysis in C-H Arylation: Direct cross-coupling of azoles with arylboronic acids using air as sole oxidant. Chem Cat Chem 2010;2:1403-6.

14. Alagille D, Baldwin RM, Tamagnan GD. One-step synthesis of 2 -arylbenzothiazole ('BTA') and -benzoxazole precursors for in vivo imaging of $\beta$-amyloid plaques. Tetrahedron Lett 2005;46:1349-51. 